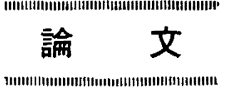

UDC 669.162 .266 .42

\title{
流体力学にもとづく高炬炬床での溶涬の流れの 検討と残㳯量と出㳯条件の関係の検討*
}

\author{
福 武 剛**. 岡 部 俠 乱***
}

\begin{abstract}
Investigation of Slag Flow in the Blast Furnace Hearth Based on the Fluid Dynamics and of Relation between Residual Slag Amount and Tapping-out Conditions
\end{abstract}

Tsuyoshi FukUTAKe and Kyoji OKABE

\begin{abstract}
Synopsis:
In order to clarify the causes of the excess accumulation of molten materials in the blast furnace hearth which results in blast furnace troubles, such as hanging and slipping, the behaviour of flowing out and accumulation of slag in the furnace hearth is investigated.

The results of model studies of slag flow in the furnace hearth during tapping were analyzed as the scaleup problem based on the theories of fluid dynamics. The dimensionless flow-out coefficient $F_{L}$ in eq. (32) has been found to be closely related to the slag residual ratio, i.e. the ratio of residual amount of slag at the end of tapping to that accumulated at the begining(Fig. 8).

Further investigation using this relation shows that eight independent variables, i.e. viscosity, tapping amount, tapping rate and depth of slag, hearth diameter, effective hearth area, number of tapping and permeability of packed coke, determine the behaviour of flowing out and accumulation of slag in the furnace hearth. The results of investigations are as follows;

1) The residual amount of slag and the depth of slag layer increase with the increase in slag tapping rate and of slag viscosity.

2) The increase of the number of tapping operation is beneficial in maintaining the smooth furnace operation, if the tapping rate and/or slag viscosity increase.
\end{abstract}

(Received Sept. 3, 1973)

\section{1. 緒}

\section{言}

高炉の炉床にたまつた溶融物（溶銑，溶涬）は，出銑 出㳯時に炬外人排出される. 溶融物の排出が不十分で, 柜床が溶融物で充満すると, 送風生力が上昇し, 装入物 降下速度が低下し，スリップが発生するなどの炉況異常 が起こる.このような炬況の悪化は通常の操業時にも起 こり, とくに大型高炉の操業においては, 出銑遅れなど の際にしばしば起こる.

YATSUZUKA ら $5^{1)}$ は大型高炉の操業について検討し, 出 銑荒れなどによる炉床内の溶融物（とくに溶滓）を十分 に排出できなくなることが高炉の生産性向上を妨げる要 因の一つであると述べている。

炉床内の溶融物量が増すのは, 出銑, 出㳯中に炉床の 溶融物が十分排出されず，出鉄終了時にも炉床内に相当 量の溶融物が残留しているためと考えられる. 出銑終了
時の忓内残留溶融物量が増すのは, 出銑中に出銑口径が 急速に拡大することなどにより出銑口から溶銑，溶㳯と

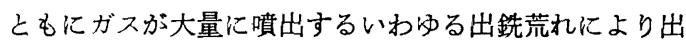
銑を早期に止めるような場合に多いことが経験的に知ら れていて，出銑中の摩耗の少ない出銑口を作るために出 銑口充てえ材の改良などが行なわれてきた2)3.

しかし，炬況に直接影響する炉床内の残留溶融物量が どのような要因により決定され，炉床内の残留溶融物量 を少なくするにはどのような出銑作業を行なうべきかと いう点に関する研究は少ない。

最近の日本の高炉操業では, 従来のように出㳯口から 出㳯を行ならことはまれで，通常すべての溶㳯を出銑口

\footnotetext{
* 昭和 47 年 10 月本会講演大会にて発表 昭和 48 年 9 月 3 日受付

** 川崎製鉄 (株) 技術研究所

*** 川崎製鉄 (株) 技術研究所工博
} 
から溶鉄とともに排出している，炉床では，溶銑層の上 に溶㳯がたまつているので, 溶㳯とガスの界面が出銑口 に到達したとき出銑を止めなければならない、したがつ て炉床に蓄皘した溶融物を十分に排出し, 安定な炉況を 維推する出銑, 出㳯条件を求めるためには, 出銑, 出㳯中 の炉床内の溶㳯の動きを明らかにし, 溶㳯の液面が出銑 口に達したときの师床内残留溶融物量に及ぼす要因の種 類とその影響を定量的に明らかにしなければならない.

下間ら45) は模型実験により出銑荒れの解析を行なつ たが, 炉床内の溶融物を溶銑のみと考え，上述のようによ り重要であると考えられる溶㳯の影㗽については無視し ている.さらに炉床に存在していると考えられるコーク ス層の影響を定量的に取り报つていないので，この実験 結果をそのまま実際の高炬に適用するのは困難である.

本研究の目的は, すべての溶㳯を出銑口からのみ排出 する場合について, 高炉炉床内の溶滓の移動に影響を及 ぼす要因を明らかにし, 出銑終了時の残滓量と出㳯開始 時の溶滓層の厚さに及ぼすこれら要因の影響を定量的に 示し, 適正な出洋条件を求める方法を示すことにある。

\section{2. 炉床における溶㳯の流れの スケールアップの条件}

出㳯時に炬床内の溶㳯の流れは 3 次元非定常流れであ る.このような流れを解析的に解くことは不可能であ り, 数値計算も多大の計算時間を要することから困難で ある.したがつてここでは, 模型実験により炉床内の溶 滓の流れを調查する.

模型実験結果を高炬操業に適用するためには, スケー ルアップの条件を明らかにし，これに基づいて実験を行 なう必要がある、本章では炉床における溶滓の流れの状 態に関する考察をもとに溶滓の流れの運動方程式を求 め, この運動方程式と初期条件, 境界条件を無次元化す るととによりスケールアップの条件を求める.

\section{1 炉床の溶溹の流れに関する考察と仮定}

操業中の高炉の炉床の状態を調查した例はなく, 炉床 の状態を知る手がかりは解体高炉の調査結果に求めざる をえない，高炉を操業中の状態のまま吹き止めたときの 調查結果6) や試験高炉の解体調査結果7) によれば, 炉底 にはほほ出銑口の下まで達しているコークス層があり, このコークス層内の上部に溶滓, 下部に溶銑が蓄積して いる.

操業中の师床の状態をこれらから類推することには問 題があるが，炉床においてコークス層が溶融物層にうか んでいると考えるのが妥当と思われる.コークス層が溶 融物層に沈えでいる深さについては, 操業中の高炉にお
ける実測例がないが，TLEUGABULOV ら゙) は操業データ の解析からコークス層が出銑口またはそれ以下の水準ま で沈えでいる可能性を指摘している*.

下間ら4)5) の研究結果が高炉に適用できると仮定する 々, 出銑口からガスが噴出するときの残留液面高さは, 出銑口径の数倍であり, 大きく見積つても $50 \mathrm{~cm}$ 程度で ある. 炉床径 $10 \mathrm{~m}$, 出銑量 $6000 \mathrm{t} /$ day, 出滓量 1800 $t /$ day の高炬の場合, $1 \mathrm{~min}$ あたり生成する溶融物量は 約 $1 \cdot 1 \mathrm{~m}^{3}$ である. 出銑止から次回の出銧開始を約 $60 \mathrm{~min}$ とすれば, 出銑開始時に炉床にたまつた溶融物の高さは, 前述の残留溶融物を加えて約 $1.4 \mathrm{~m}$ にすぎない，炉床径 $10 \mathrm{~m}$ の高炉では, 出銑口と羽口間の距離は 3〜 3. $5 \mathrm{~m}$ で あり，出銑開始時の液面は羽口平面までの高さの半分に もならない．このことは，10３0 min 程度の出銑遅れに より風圧上昇などの炉況異常が起こるという高炬操業の 経験を説明できない，これは，炉床にコークス層がない と仮定したためで，下間らし) は炉床に充て几物が存在 するときは, 残留液面高さが著しく増加すると述べてい る. そこで本研究では, 出㳯開始時にコークス層が出銑 口まで存在し, 溶滓はコークス層内を移動すると仮定し た.

出銑初期に溶銑のみが流出している間は炉床内での溶 滓の動きは小さいので出㳯開始までの溶㳯の液面の形 （溶滓一ガス界面）は，液面近傍のガスの圧力分布によ り決まる. 溶㳯の液面が高炉の羽口水準のごく近傍か それ以上にある場合には，レースウェイから出てくるガ スの圧力分布により溶㳯の液面は水平ではない。しか し, 通常の操業では溶㳯の液面は, 羽口水準よりいくぶ 几下にあるので, 溶㳯の液面はほぼ水平とみなせる年10). 溶滓の液面でのガス圧力分布は，溶澾の液面の形に影飨 し，溶㳯層の下にある溶銑層には影響しないので溶銑の 液面（溶銑一溶㳯界面）は, もつぱら溶銑の移動により 決まる.出銑中の溶鉄の移動により溶銑の液面はいくぶ ん出銑口に向けて下がつた傾斜をしているものと推定さ れる.

ここでは次のような仮定を設けて炉床の溶㳯の流れを 単純化し実験を行なう.

（1）炉床では，出㳯開始時にコークス層が出銑口ま で存在し，溶涬はこのコークス層を通つて出銑口へ移動 する。

（2）出㳯開始時に溶滓の液面は水平である.

（3）溶銑の液面は出銑中水平である（この仮定の妥 当性は後で検討する).

* 踰文中に用いられている “hearth filling coefficent” $\kappa_{\mathrm{Lf}}$ の定義式

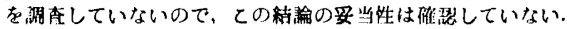


（4）出滓速度は出漳中一定である.

（5）炉床内は等温である.

（6）炉床内のコークスは一椂に充さんされている. すなわち，空間率と粒子径は一㥞である.

\section{2 炉床の溶㳯の流れの選動方程式}

前述のように，炉床内ではコータス層の中を溶滓が移 動すると考えるので，出銑中の溶㵏の流れは充てえ層内 の液体の非定常流れとみなせる.

充てん層内のガス流れについての運動方程式を作成 し，これを数值的に解く試みは $J$. RADESTOCK ら 11)1213) により行なわれている. 著者ら ${ }^{9) 10)}$ は同様の運動方程式 を無次元化し，充てん層内の圧力分布のスケールアップ の条件の妥当性をモデルによる測定値を用いて検討し た、これらの報告では，個々の充てん粒子のまわりを流 れる流体の微視的な運動をとらえるのではなく，充てえ 層内の流れを巨視的にとらえて，充てん層中の流れの主 流についての運動方程式を導いている.

多孔体 (Porous media) 中の液体の流れに関しては, 従来 Darcy の式，あるいはその変形式を用いた解析が 行なわれている. しかし，Darcyの式がここで考えてい るような比較的粗い粒子の充てん層で，かつ流れの主流 が直線でなく曲線の場合にも無条件で成り立つか否かに ついては必ずしも明らかでない。

そこで前述の $J$. RADESTOCK らが示した運動方程式 と同样の考え方に基ゔき，流体の粘性力が充てん層の圧 力損失に相当するものとして運動方程式を導いた。

非圧縮性のニ (1)，(2) 式により示される14).

$$
\begin{aligned}
& (\nabla \cdot \boldsymbol{v})=0 \\
& \rho \frac{D \boldsymbol{v}}{D t}=-\nabla p+\mu \nabla^{2} \boldsymbol{v}+\rho \boldsymbol{g}
\end{aligned}
$$

たシだし

$$
\frac{D}{D t}=\frac{\partial}{\partial t}+v_{x} \frac{\partial}{\partial x}+v_{y} \frac{\partial}{\partial y}+v_{z} \frac{\partial}{\partial z} \text { である. }
$$

充てん層内の流れの場合には前述のように（2）式中 の粘性項 $\mu \nabla^{2} \boldsymbol{v}$ のかわ和りに充てえ層を通る流体の圧力損 失に相当する力が充てん層から主流にかかるとみなし采 に加わる外力として取り扱う.

充てん層内の流れの圧力損失は, $\mathrm{g}$ 重 $/ \mathrm{cm}^{2} / \mathrm{cm}$ のよう に力/体積の次元を持つ. 圧力損失は流れの方向に発生 するのでこの外力（圧力損失項）は，流れの方向の逆向 きに充てん物から流体にかかる体積力である．流れ方向 の流速を $V(=|\boldsymbol{v}|)$, 圧力損失項のベクトルを $\boldsymbol{R}$, その 大きさを $R(=|\boldsymbol{R}|)$, とおくと, $\boldsymbol{v}$ と $\boldsymbol{R}$ は逆向きであ るから（3）式が成り立つ.

$$
\boldsymbol{R}=-\boldsymbol{R} \boldsymbol{v} / V
$$

溶滓の流出流量を炉床の断面積で割つた溶㳯の炉床内 平均流速 $V_{0}$ をとに粒子レイノルズ数を求めるとTable 5 に示すように小さい值となり，炉床内の溶滓の流れは 層流域にあると考えられる. $\boldsymbol{R}$ は充てえ層内の流れの単 位長さあたりの圧力損失に等しいので層流域における充 てえ層の圧力損失式 ${ }^{15)}$ を生力損失の単位が $\mathrm{dyn} / \mathrm{cm}^{3}$ に なるように変換して，（4）式で示される.（4）式中の $\varepsilon$ は $V$ 空塔速度に換算するときの倸数である.

$$
\begin{aligned}
& R=C_{\mathrm{B}} V \varepsilon \\
& C_{\mathrm{B}}=180(1-\varepsilon)^{2} \mu /\left(\varepsilon^{3} \phi_{\mathrm{s}}{ }^{2} D_{\mathrm{p}}{ }^{2}\right)
\end{aligned}
$$

充てん層内の流体が通る空問と断面皘は，ともに充て ん層全体の空間, 断面皘の $\varepsilon$ 倍となる. $\varepsilon$ は仮定により 一定であり，（1），（2）式の各項と $\boldsymbol{R}$ に共通に乘ぜら れるので簡約でき, 結局充てん層内の非定常な流体の流 れは, 連続の式（1）と運動方程式（6）で示される.

$$
\rho \frac{D \boldsymbol{v}}{D t}=-\nabla p-\varepsilon C_{\mathrm{B}} \boldsymbol{v}+\rho \boldsymbol{g}
$$

装置の境界あるいは液面を示す式を

$$
\phi(x, y, z, t)=0 \cdots
$$

とすると一般に境界条件は（8）式により示される16).

$$
\frac{D \psi}{D t}=0
$$

z軸が鉛值方向になるように座標系をとると, 液面の 高さ $(z)$ は $x, y, t$ の 1 価関数なので液面を示す方 程式を（9）式で示すことができる.

$$
\psi_{\mathrm{s}}=z-f_{\mathrm{S}}(x, y, t)=0 \ldots
$$

上部から液体の供給がない場合には， $\psi_{\mathrm{s}}$ を(8)式の $\phi$ に代入し，定義式にしたがつて偏微分方程式に書き換え ると液面を示す関数 $f_{\mathrm{S}}$ について (10) 式が成り立つ.

$$
\frac{\partial f_{\mathrm{S}}}{\partial t}=v_{z}-v_{x} \frac{\partial f_{\mathrm{S}}}{\partial x}-v_{y} \frac{\partial f_{\mathrm{S}}}{\partial y}
$$

ただしここでは $v_{x}, v_{y}, v_{z}$ はそれぞれ液面上の流速成 分とする. 装置の上部から液体が一㤘以供給されると き, (10) 式は (11) 式に変形できる.

$$
\frac{\partial f_{\mathrm{s}}}{\partial t}=v_{\mathrm{I}}+v_{z}-v_{x} \frac{\partial f_{\mathrm{s}}}{\partial x}-v_{y} \frac{\partial f_{\mathrm{s}}}{\partial y}
$$

液面の压力はこの部分のガス圧力と等しいので，液面 $z$ $=f_{\mathrm{s}}$ での境界条件は (12) 式で示される.

$$
p=p_{0}
$$

流出口においては (13) 式が境界条件を示す.

$$
\boldsymbol{v} \mid \text { 流出口 }=\boldsymbol{v}_{0}
$$

初期条件は流出開始時の液面高さを与える (14) 式で 示される.

$$
f_{\mathrm{s}}(x, y, 0)=D_{\mathrm{H}}
$$

(1), (6), (8), (11), (12), (13), (14)式により 
炉床内の溶滓の流れがあらわせる。

\section{3 スケールアップの条件の検討}

スケールアップの条件は, 上述の運動方程式を無次元 化することにより求められる.ここでは，上述の方程式 の各变数を次のように無次元化する ${ }^{14)}$ (無次元変数を添 字*で示す).

$$
\begin{aligned}
& x^{*}=x / D_{\mathrm{T}}, \quad y^{*}=y / D_{\mathrm{T}}, \quad z^{*}=z / D_{\mathrm{T}} \\
& t^{*}=t V_{0} /\left(\varepsilon D_{\mathrm{T}}\right) \\
& p^{*}=\left(p-p_{0}\right) \varepsilon^{2} /\left(\rho V_{0}{ }^{2}\right) \\
& \boldsymbol{v}^{*}=\varepsilon \boldsymbol{v} / V_{0} \\
& \boldsymbol{g}^{*}=\boldsymbol{g} / \mathrm{g}
\end{aligned}
$$

オペレーターは次式により無次元化できる.

$$
\begin{aligned}
& \nabla^{*}=\nabla / D_{\mathrm{T}} \\
& \frac{D}{D t^{*}}=\frac{D_{\mathrm{T} \varepsilon}}{V_{\mathbf{0}}} \frac{D}{D_{t}}
\end{aligned}
$$

(15)〜 (21) 式を用いて上述の式を無次元化する. 式から

$$
\left(\nabla^{*} \cdot \boldsymbol{v}^{*}\right)=0
$$

(6) 式から

$$
\begin{aligned}
& \frac{D \boldsymbol{v}^{*}}{D t^{*}}=-\left(\nabla^{*} p^{*}\right)-\left[\frac{C_{\mathrm{B}} D_{\mathrm{T}} \varepsilon^{2}}{\rho V_{0}}\right] \boldsymbol{v}^{*} \\
& +\left[\frac{g D_{\mathrm{T}} \varepsilon^{2}}{V_{0}^{2}}\right] \boldsymbol{g}^{*}
\end{aligned}
$$

(11) 式から

$$
\frac{\partial f_{\mathrm{s}}^{*}}{\partial t^{*}}=\frac{\varepsilon v_{\mathrm{I}}}{V_{0}}+v_{z}^{*}-v_{x} * \frac{\partial f_{\mathrm{s}}^{*}}{\partial x^{*}}-v_{y} * \frac{\partial f_{\mathrm{s}}^{*}}{\partial y^{*}}
$$

(12）式から $z^{*}=f_{\mathrm{s}}^{*}$ において

$$
p^{*}=0
$$

(14) 式から

$$
f_{\mathrm{s}}^{*}\left(x^{*}, y^{*}, 0\right)=D_{\mathrm{H}} / D_{\mathrm{T}}
$$

が得られる. 装置の形状が相似であれば, 装置の壁面, 底面, 流出口での境界条件の相似は容易に得られるので スケールアップの条件は $(22) \sim(26)$ 式中に現われる無 次元数

$$
\begin{aligned}
R_{\mathrm{eb}} & =\rho V_{0} /\left(\varepsilon^{2} C_{\mathrm{B}} D_{\mathrm{T}}\right) \\
F_{\mathrm{r}} & =V_{0}^{2} /\left(g D_{\mathrm{T}} \varepsilon^{2}\right) \\
R_{\mathrm{V}} & =V_{0} /\left(\varepsilon v_{1}\right) \\
D_{\mathrm{H}}^{*} & =D_{\mathrm{H}} / D_{\mathrm{T}}
\end{aligned}
$$

が装置とモデルで等しくなることである， $R_{\mathrm{eb}} ， F_{\mathrm{r}}$ は運 動の相似条件を与兄, $R_{\mathrm{eb}}$ は, 流れの慣性力と充て几層 の摩擦力の比を示し, 二ュートン流れの場合のレイノル ズ数と同様の意味を持つている． $F_{\mathrm{r}}$ 快慣性力と重力の 比を示し， $\varepsilon$ を除けぼフルード数に一致する. $R_{\mathrm{v}}, D_{\mathrm{H}}{ }^{*}$ はそれぞれ境界条件と初期条件を定める無次元数である これらの無次元数注装置とモデルの流れの相似条件を

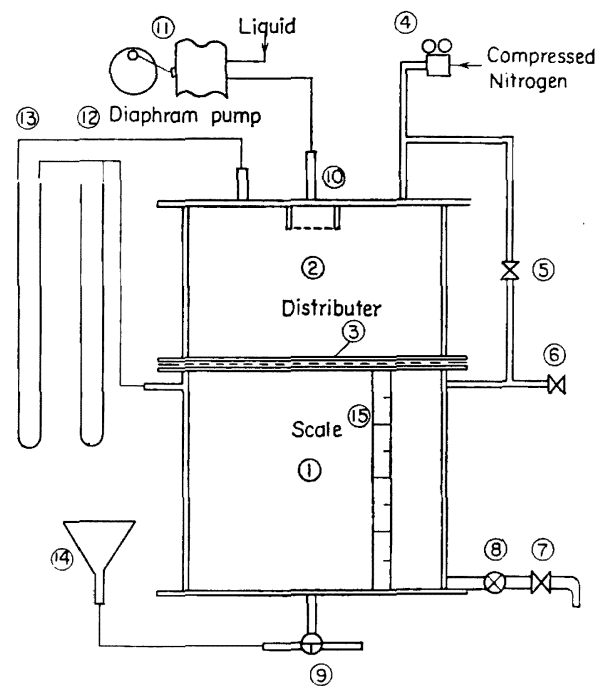

Fig. 1. Experimental apparatus (for continuous experiment).

Table 1. Sizes of glass beads used as packed material.

\begin{tabular}{c|c|c|c}
\hline Number of beads & 4 & 7 & 9 \\
\hline Size range $(\mathrm{mm})$ & $2 \cdot 0-2 \cdot 38$ & $3 \cdot 36-4.0$ & $4 \cdot 76-5 \cdot 66$ \\
\hline $\begin{array}{c}\text { Mean diameter } \\
(\mathrm{mm})\end{array}$ & $2 \cdot 18$ & $3 \cdot 67$ & $5 \cdot 19$ \\
\hline
\end{tabular}

与えているので，モデル実験結果をこれらの無次元数に より整理することができる。

\section{3.モテル実験と結果の整理}

前章の考察から, 炉床の溶滓の流れは (27) 〜 (30) 式 で示される 4 つの無次元数により決まることがわかつ た.しかし，これらの影響を同時に明らかにするのは， 実験条件の設定と結果の解析が複雑になることから困難

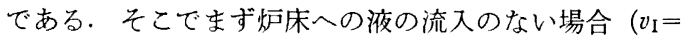
0 ，バッチ実験）について実験し， $R_{\mathrm{eb}} ， F_{\mathrm{r}}$ と $D_{\mathrm{H}}^{*}$ が溶 洋の流出状態に及ぼす影響を明らかにし，ついで液を連 続的に流入させる連続実験を行なつた。

\section{1 実験装置之穾験方法}

Fig. 1 亿連続実験装置を示す，装置は透明アクリル樹 脂製の円筒で内径 $140 \mathrm{~mm} \phi$ である. バッチ式の実験装 置は，上部の液体だめと分散板がない点を除いて Fig. 1 のものと同様であり, 内径 $190 \mathrm{~mm} \phi$ と $150 \mathrm{~mm} \phi$ の 2 種類製作した.

炉床のコークスのかわりの充てえ物として Table 1 に示すように粒度の異なるガラス玉 3 種類を用いた。液 
Table 2. Properties of liquids used for the experiments.

\begin{tabular}{|c|c|c|c|c|}
\hline Liquid & Symbol & $\begin{array}{l}\text { Glycerol concent- } \\
\text { ration }(\%)\end{array}$ & $\begin{array}{l}\text { Density } \\
\left(\mathrm{g} / \mathrm{cm}^{3}\right)\end{array}$ & $\begin{array}{l}\text { Viscosity } \\
\text { (centipoise) }\end{array}$ \\
\hline $\begin{array}{l}\text { Aqueous } \\
\text { glycerol }\end{array}$ & $\begin{array}{l}\mathrm{A} \\
\mathrm{B} \\
\mathrm{C}\end{array}$ & $\begin{array}{l}84 \cdot 0 \\
71 \cdot 0 \\
46 \cdot 0\end{array}$ & $\begin{array}{l}1 \cdot 216 \\
1 \cdot 181 \\
1 \cdot 113\end{array}$ & $\begin{array}{c}99 \cdot 6 \\
25 \cdot 2 \\
4.95\end{array}$ \\
\hline Tetrabromoethane & $\mathrm{D}$ & - & $2 \cdot 967$ & $10 \cdot 8$ \\
\hline
\end{tabular}

Table 3. Experimental conditions (batch-type experiments).

\begin{tabular}{|c|c|c|c|c|}
\hline Exp. No & $\mathrm{D}_{\mathrm{H}}{ }^{*}$ & Liquid & Glass bead & $\begin{array}{l}\text { Apparatus } \\
\text { diameter }(\mathrm{mm})\end{array}$ \\
\hline $\begin{array}{c}\mathrm{A}-1-\mathrm{A}-5 \\
\mathrm{~B}-\mathrm{1}-\mathrm{B}-5 \\
\mathrm{C}-1-\mathrm{C}-5 \\
\mathrm{D}-1-\mathrm{D}-6 \\
\mathrm{E}-5 \\
\mathrm{~F}-5 \\
\mathrm{G}-5 \\
\mathrm{H}-5 \\
\mathrm{I}-5 \\
\mathrm{~J}-1-\mathrm{J}-3 \\
\mathrm{~K}-1-\mathrm{K}-3\end{array}$ & $\begin{array}{c}0 \cdot 121-0 \cdot 471 \\
0 \cdot 121-0 \cdot 471 \\
0 \cdot 121-0.471 \\
0 \cdot 121-0.921 \\
0 \cdot 471 \\
0 \cdot 471 \\
0 \cdot 471 \\
0 \cdot 471 \\
0 \cdot 471 \\
0 \cdot 40-1 \cdot 0 \\
0 \cdot 40-1 \cdot 0\end{array}$ & $\begin{array}{l}\text { A } \\
\text { B } \\
\text { C } \\
\text { A } \\
\text { C } \\
\text { A } \\
\text { B } \\
\text { B } \\
\text { C } \\
\text { B } \\
\text { D }\end{array}$ & $\begin{array}{l}9 \\
4 \\
4 \\
7 \\
9 \\
4 \\
9 \\
7 \\
7 \\
7 \\
4\end{array}$ & $\begin{array}{l}190 \\
190 \\
190 \\
190 \\
190 \\
190 \\
190 \\
190 \\
190 \\
150 \\
150\end{array}$ \\
\hline
\end{tabular}

体は粘度を変えるために種々の濃度のグリセリン水溶液 をおもに用い，一部液体の密度の影響を確認するために テトラブロムエタンを用いた（Table 2).

ハッッ実験では充てえ物と液体の物性値の影響を検討 するために Table 3 の実験条件を選えだ，装置径の影 響（実験系列 $\mathrm{J}$ )，液密度の影響（実験系列 $\mathrm{K}$ ）もバッ 千実験で検討した。

連続実験では $R_{\mathrm{v}}$ を $1 \cdot 3 \sim 25$ の範囲で， $D_{\mathrm{H}}^{*}$ を 0.21 〜0.57 の範囲で変光, ガラス玉は No 4 (Table 1), 液体は C (Table 2) のただ1つの組み合わせで実験を 行なつた.

液体は，上部からダイアフラム式定量ボンプ (11)を用 いて（連続実験），あるいは下部からロート厌，3 方コ ック (9)を通して（バッチ実験）装置内に送つた，液面 の高さは装置外周にとりつけたスケール (15)により読み とり調整した。

流出流量は，スクリューコック (7) により調整した. 装置内汒 $\mathrm{N}_{2}$ で $0.18 \mathrm{~kg} / \mathrm{cm}^{2}$ に加佂した。これにより流 出流量が実験中ほぼ一定となることをあらかじめ確認し た. 流出の開始, 停止は 2 方コック (8)により行なつた. 停止の時期は出銑口からガスが吹き出すときに相当する ものとして，2 万コック (8) のガラス管部に気泡が現れ たときとした。

液体の粘度は, 温度により大きく変わるので, キャ， ンフェンスケ型粘度計により実験中をたは実験後に数回 測定し，その平均值を以後の解析に用いた.

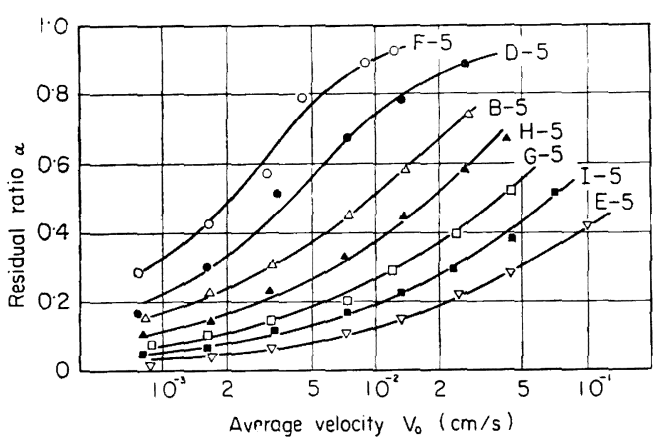

Fig. 2. Relation between residual ratio and average velocity of liquid.

\section{2 実験結果}

流出状態を示寸指標として, 流出開始時の装置内蓄秥 液量に対する流出終了時の残留液量の割合, 残留率を用 いた.

$3 \cdot 2 \cdot 1$ 残留率に及ぼす $R_{\mathrm{eb}}, F_{\mathrm{r}}$ の影響（バッチ実験） 2 章の愉討から，バッチ実験の場合 $D_{\mathbf{H}}^{*}$ が一定であ れば，残留率は $R_{\mathrm{eb}}$ と $F_{\mathrm{r}}$ により決まる、実験では $\varepsilon$ とgが一定なので, $R_{\mathrm{eb}}$ は $C_{\mathrm{B}} / \rho$ と $V_{0} に, F_{\mathrm{r}}$ は $V_{0}^{2}$ に依存する、したがつて， $R_{e b}$ と $F_{\mathrm{r}}$ が残留率に及ぼす 影響を調べるかわりに， $C_{\mathrm{B}} / \rho$ と $V_{0}$ の影響を検封した。

Fig. 2 にガラス玉と液体の種々の組み合わせ $\left(C_{\mathrm{B}} / \rho\right.$ の变化に相当）について残留卒と平均流速 $V_{0}$ の関係を $V_{0}$ を対数軸として示す.この因から残留率と $V_{0}$ の関 係を示す曲線は， $C_{\mathrm{B}} / \rho$ により異なるが，いずれも横軸 


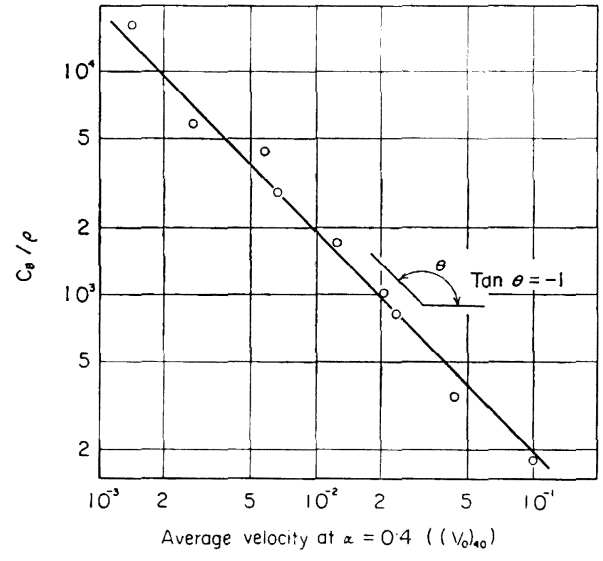

Fig. 3. Relation between $C_{\mathrm{B}} / \rho$ and the average velocity, at $\alpha=0.4\left(\left(V_{\mathbf{0}}\right)_{\mathbf{4 0}}\right)$.

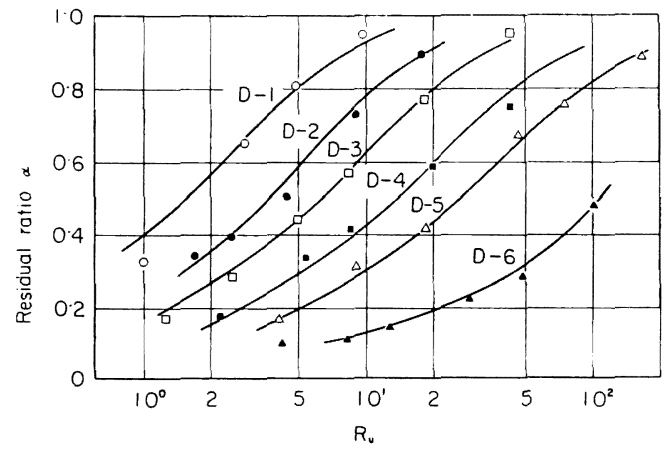

Fig. 4. Effect of the depth of liquid on the relation between residual ratio $(\alpha)$ and $R_{\mathrm{u}}$.

（対数軸）にそつた平行移動により重ね合わせられるこ とがわかる.

平行移動量を示す值として残留率 $40 \%$ のときの平均 流速 $\left(V_{0}\right)_{40}$ を用いると, $C_{\mathrm{B}} / \rho$ と $\left(V_{0}\right)_{40}$ の関係は, Fig. 3 のように両対数グラフ上で傾き -1 の直線関係を示 す.したがつて無次元液高さが一定のときには， $V_{0}$ と $C_{\mathrm{B}} / \rho_{\mathbf{2}}$ の積

$$
R_{\mathrm{u}}=V_{0} C_{\mathrm{B}} / \rho
$$

が残留率を決定する。

$3 \cdot 2 \cdot 2$ 残留晏に及ぼす $D_{\mathrm{H}}^{*}$ の影響 (パッチ実験)

$D_{\mathrm{H}}^{*}$ が一定のときは, 残留率は $R_{\mathrm{u}}$ により決まるの で，残留率と $R_{\mathrm{u}}$ の関係に及ほす $D_{\mathrm{H}}^{*}$ の影響を検討す る. Fig. 4 に実験系列 $D$ について種々の $D_{\mathrm{H}} *$ の場合 の残留率と $R_{\mathrm{u}}$ の関係を示す. Fig. 3 と同様に各曲線は 横軸 (対数軸) にそう平行移動により重ね合わせられる ので，平行移動を示す值として残留率 $50 \%$ のときの $R_{\mathrm{u}}$ の值 $\left(R_{\mathrm{u}}\right)_{50}$ を用いこれと $D_{\mathrm{H}}^{*}$ の関係を調べた.

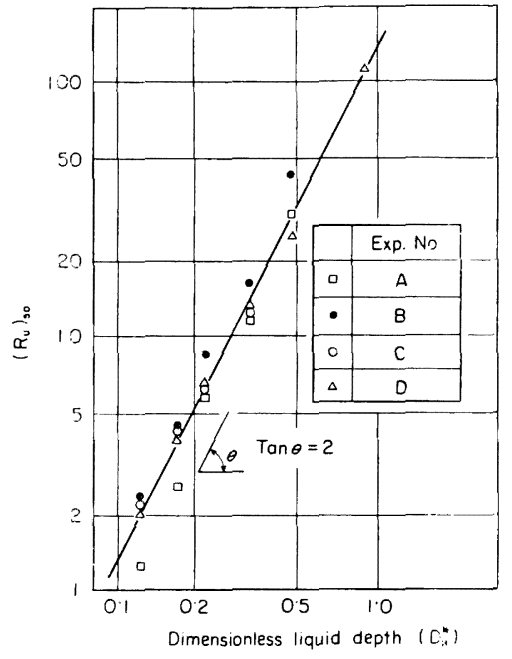

Fig. 5. Relation between $R_{\mathrm{u}}$ at $\alpha=0.5\left(\left(R_{\mathrm{u}}\right)_{50}\right)$ and dimensionless liquid depth $\left(D_{\mathrm{H}}^{*}\right)$.

両对数グラフ上の $\left(R_{\mathrm{u}}\right)_{50}$ と $D_{\mathrm{H}}^{*}$ の関係 (Fig. 5) から, 両者は傾き 2 の直線関係にあるこがわかる. した がつて液の流入のないバッチ実験の場合, 残留率は $R_{\mathrm{u}}$ と $D_{\mathrm{H}}^{*}$ の自乗の比 $R_{\mathrm{u}} / D_{\mathrm{H}}^{*}$ により決まる.

\section{$3 \cdot 2 \cdot 3$ バッチ実験結果の総括}

2 章における検討から, バッチ実験の条件では, 残留 率は $R_{\mathrm{eb}}, F_{\mathrm{r}}, D_{\mathrm{H}}^{*}{ }^{2}$ により決まる. 一方実験で变化し うる变数の範用では, 残留率は $R_{\mathrm{u}} / D_{\mathrm{H}}^{*}$ により決まる. $R_{\mathrm{u}}$ の $C_{\mathrm{B}} / \rho$ と $V_{0}$ の指数と $R_{\mathrm{eb}}, F_{\mathrm{r}}$ のそれらの指数 の比較により $R_{\mathrm{u}}$ は $F_{\mathrm{r}}$ と $R_{\mathrm{eb}}$ の比に相当しているこ

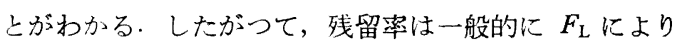
決まると推定できる。

$$
\begin{aligned}
F_{\mathrm{L}} & =F_{\mathrm{r}} /\left(R_{\mathrm{eb}} D_{\mathrm{H}}^{* 2}\right) \\
& =\frac{C_{\mathrm{B}} V_{\mathrm{o}}}{\rho g}\left(\frac{D_{\mathrm{T}}}{D_{\mathrm{H}}}\right)^{2} \\
& =180 \frac{(1-\varepsilon)^{2}}{\varepsilon^{3}} \frac{1}{\phi_{\mathrm{s}}{ }^{2} D_{\mathrm{p}}{ }^{2}} \frac{\mu}{\rho}-\frac{V_{\mathrm{o}}}{g}\left(\frac{D_{\mathrm{T}}}{D_{\mathrm{H}}}\right)^{2}
\end{aligned}
$$

(32) 式の $R_{\mathrm{eb}}$ と $F_{\mathrm{r}}$ の項は理論的に導いたものであ るから, 上述の実験で検討していない液密度, 装置径の 影響についても (32) 式で評価しうると考えられ装置径 は残留率に影響を及ぼさないと予想される. Fig. 6 に Table 3 に示す種々の実験結果を一括して示す.実線は, 実験結果をもつともよく代表するように引いたもので， 残留率と $F_{\mathrm{L}}$ の関係を示す，この図から装置径の異なる 実験系列 $\mathrm{J}$, 液密度の異なる実験系列 $\mathrm{K}$ のデータが, 他のデータとよく一致していることがわかり，残留率を $F_{\mathrm{L}}$ により示すのが妥当であることがわかる. 


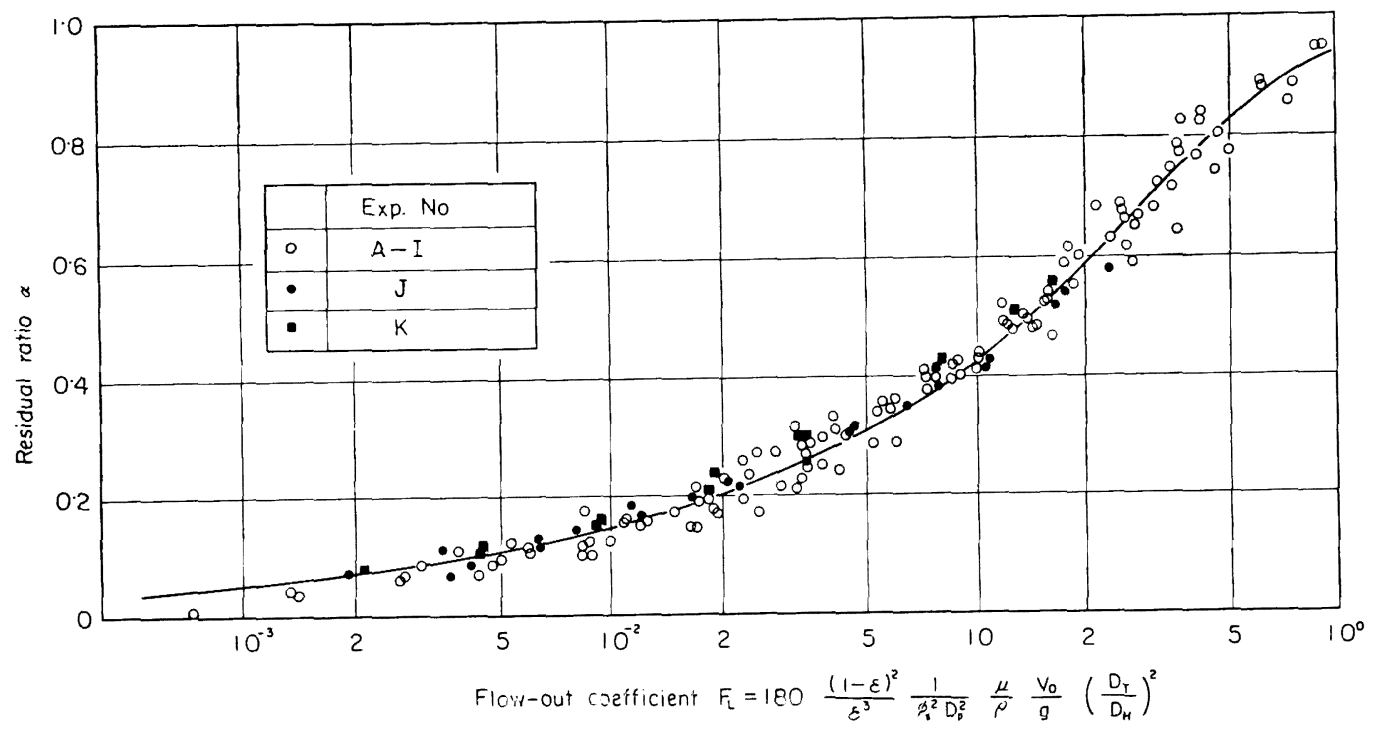

Fig. 6 . Relation between residual ratio and flow-out coefficient $F_{\mathrm{L}}$ (summary of batch experiments including confirmation on the effects of the diameter of apparatus ( $\mathbf{J})$ and of the density of liquid $(\mathrm{K})$ )

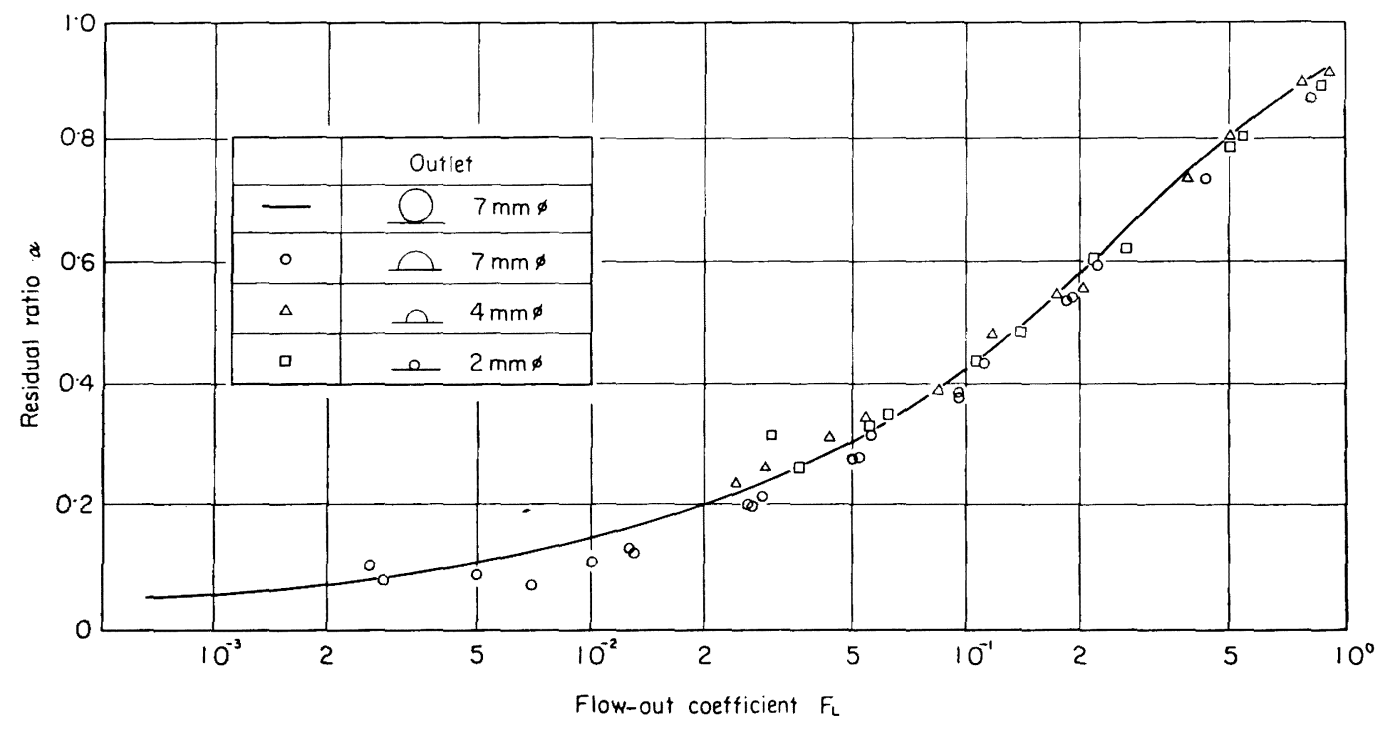

Fig. 7. Infiuence of the shape of outlet on the relation between $\alpha$ and $F_{\mathrm{L}}$.

\section{2 .4 流出口の形の影響（パッチ実験）}

Fig. 6 のデータはすべて同一の流出口を持つ装犆によ り得た．高炉の場合炉床径で割つた無次元出銑口径は約 0.01であるが，モデル装置では約 0.035 であつた．境 界条件を相似に保つためには，両者を同一の值にする必 要があるが，モデルの流出口径を小さくすることは困難
であるそそこで $140 \mathrm{~mm}$ の装置により流出口の形を变 えてバッキ実験を行なつた。

このときの残留率と $F_{\mathrm{L}}$ の関係を示す Fig. 7 から, 流出口の形は残留率と $F_{\mathrm{L}}$ の関係に影響しないことがわ かる．流出口の形は流出口付近のごく限られた範囲の流 れに影響するにすぎないと考えられ，本実験結果から高 


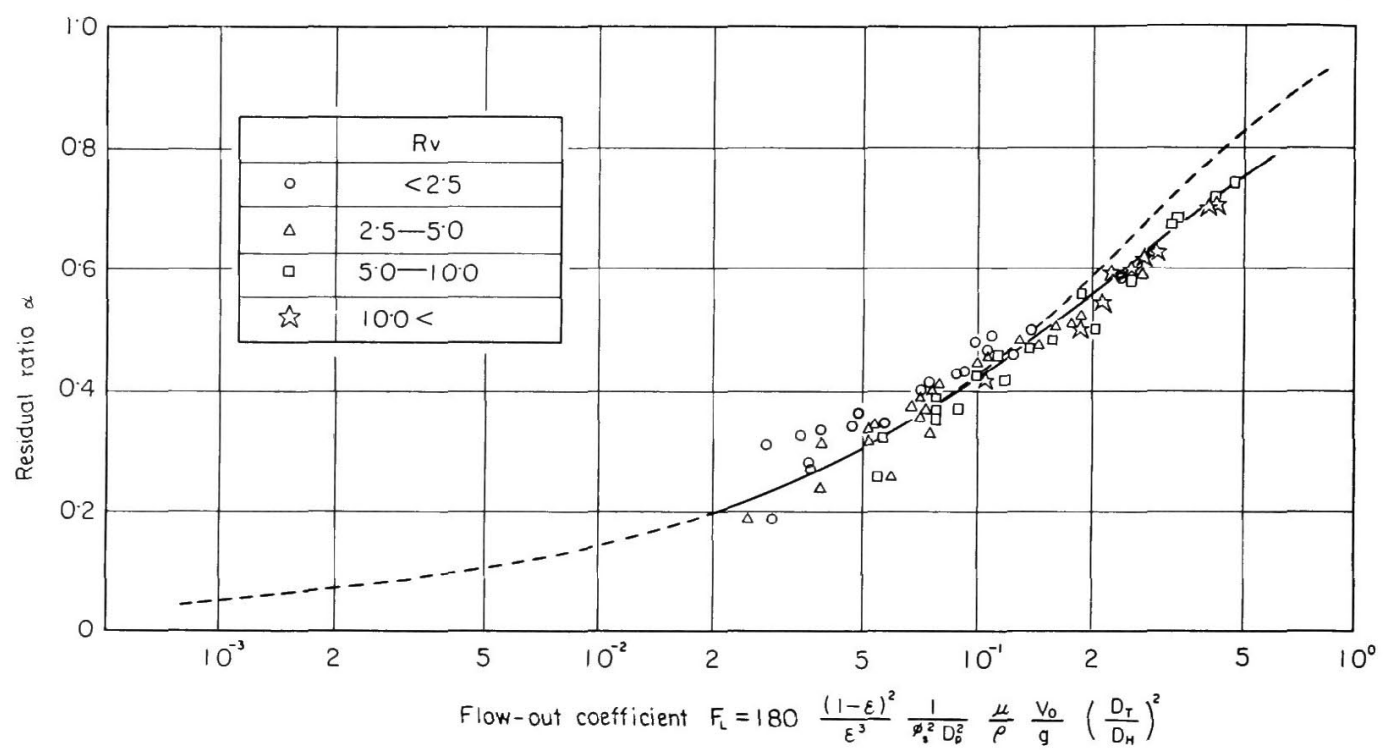

Fig. 8. Result of continuous experiments (dotted line shows the result of batch experiments).

炉出銑口とモデルの流出口の形の差異は無視しうる.

$3 \cdot 2 \cdot 5$ 連続実験結果

Fig. 8 に連続実験の場合について，バッチ実験の場合 と同样に，残留率と $F_{\mathrm{L}}$ の関係を示す. 各点は連続実娩 の場合あらたに追加される境界条件である $R_{\mathrm{v}} に よ り$ 層 別した. 残留率と $F_{\mathrm{L}}$ の関倸を示す曲線は, 連続実験結
果（実線）とバッチ実験結果（点線）とで $F_{\mathrm{L}}$ が $0 \cdot 15$ より高い部分を除き両者とも同一である. バッチ実験と 比較して連続実験のデータは $F_{\mathrm{I}}$ の範囲が狭いが， $F_{\mathrm{L}}$ の 小さいところでは，バッチ実験の結果と一致している. したがつて $F_{\mathrm{L}}$ の小さいところでは, バッチ奏験の結果 により連続実験結果を外插できる.
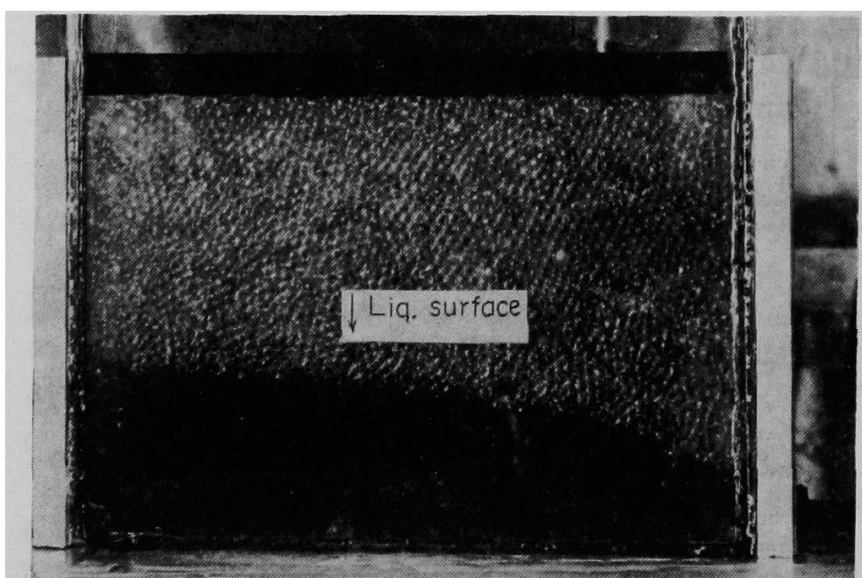

Liquid outlet

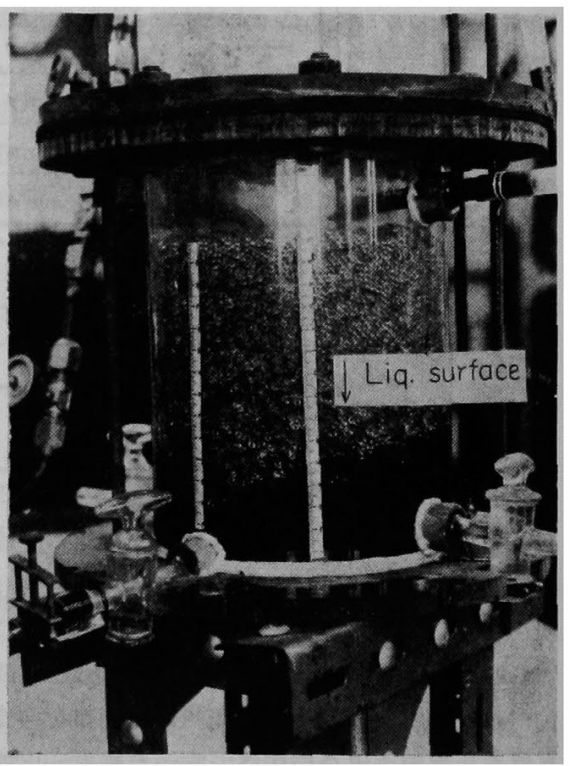

(b)

(a)

Photo. 1. Inclined liquid surface formed during flow-out of the liquid on (a) the model used to these experiments and (b) two-dimensional model. 
Table 4. Size analysis of the coke sampled from the blast furnace hearth (excluding the part less than $5 \mathrm{~mm}$ ).

\begin{tabular}{|c|c|c|c|c|c|c|c|c|}
\hline \multirow{2}{*}{ Sample* } & \multicolumn{5}{|c|}{ Size analysis $(\mathrm{mm})$} & \multirow{2}{*}{$D_{\mathrm{p}}$} & \multirow{2}{*}{$I_{\mathrm{sp}}$} & \multirow{2}{*}{$C_{0} \Phi_{0}$} \\
\hline & +50 & 25 & 15 & 10 & 5 & & & \\
\hline $\begin{array}{l}A \\
B \\
C \\
D\end{array}$ & $\begin{array}{r}11 \cdot 8 \\
9 \cdot 5 \\
15 \cdot 3 \\
9 \cdot 0\end{array}$ & $\begin{array}{l}54 \cdot 0 \\
50 \cdot 5 \\
56 \cdot 7 \\
65 \cdot 5\end{array}$ & $\begin{array}{l}20 \cdot 2 \\
21 \cdot 8 \\
22 \cdot 2 \\
18 \cdot 1\end{array}$ & $\begin{array}{l}7 \cdot 8 \\
9 \cdot 1 \\
3 \cdot 2 \\
4 \cdot 3\end{array}$ & $\begin{array}{l}6 \cdot 2 \\
9 \cdot 1 \\
2 \cdot 6 \\
3 \cdot 1\end{array}$ & $\begin{array}{l}24 \cdot 0 \\
20 \cdot 3 \\
27 \cdot 4 \\
26 \cdot 7\end{array}$ & $\begin{array}{l}51 \cdot 0 \\
56 \cdot 1 \\
32 \cdot 2 \\
31 \cdot 9\end{array}$ & $\begin{array}{l}0 \cdot 830 \\
0 \cdot 853 \\
0 \cdot 741 \\
0 \cdot 740\end{array}$ \\
\hline
\end{tabular}

* A: Sampled from the tuyer of No 1 BF at Mizushima Works

B, C, D: Sampled from the hearth of No $4 \mathrm{BF}$ at Chiba Works

Fig. 8 において，各点の曲線からの偏位は小さいが， $R_{\mathrm{v}}$ が最低のデータ (図中○印) はいくぶん上方にかた よつている.しかし $R_{\mathbf{v}}$ が他の範囲にあるデータはほぼ 曲線の両側に位置しているので，この実験の精度篹囲で は $R_{\mathrm{v}}$ が残留率と $F_{\mathrm{L}}$ の関係に及ぼす影響は少ないと考 えられる。

したがつて連続実験の場合も残留率は $F_{\mathrm{L}}$ により決定 され, 残留蜜と $F_{\mathrm{L}}$ の関係は Fig. 8 の実線と, $F_{\mathrm{L}}$ の低 い領域への点線による外挿により示される.

ガス噴出時に装置内に多量の液体が残る原因は, 下間 ら45) の示した『うず』によるのではなく，流体が充て ん層を通るため流出中に液面が流出口に向つて下つた傾 斜になるためであることが本モデル (Photo．1a）上箱 形の 2 次元模型 (Photo. 1 b ) による流出中の液面の変 化の観察から明らかになつた.

\section{4. 考察}

\section{1 スケールアップの制限条件}

実験結果を高炉に適用するためには，スケールアップ の条件として 2 章で得た無次元数について，高炉炉床内 の条件で計算した値が実験値の範囲内になければならな いししし2 幛で示したように高炉炉床の条件を正確に 求めることは困難なので, 適切な仮定をもうけ的闲ての 各無次元数を計算した.

スケールアップの条件となる無次元数は， $R_{\mathrm{eb}}, F_{\mathrm{r}}$, $R_{\mathrm{v}}, D_{\mathrm{H}}^{*}$ であり，さらに炋床内の液体の動きは層流域に あると仮定したので，炬床の平均流速に対する粒子レイ ノルズ数

$$
R_{\mathrm{epo}}=\frac{\rho V_{0} D_{\mathrm{p}}}{\mu}
$$

も求める必要がある.

炉床における $C_{\mathrm{B}}$ の值は，高炉羽口から，あるいは 改修時に炬床でサンプリングしたコークスの粒度分析 (Table 4) をもとに以下のように推定した.

装入物の粒度分析值を用いて压力損失を推定する式 ${ }^{17)}$
を層流域に適用すれば（34）式がえられる。

$$
J p=\frac{\mathrm{I}}{g_{\mathrm{c}}} C C_{0} \phi_{0} \frac{\mu V \varepsilon}{D_{\mathrm{p}}{ }^{2}}
$$

$J p / L$ を質量単位で示すと (34) 式の $g_{\mathrm{c}}$ が消去され，

(4) 式の $R$ は (35) 式により示される.

$$
R=C C_{0} \Phi_{0} \frac{\mu V \varepsilon}{D_{\mathrm{p}}^{2}}
$$

(4), (5) 式と (35) 式を比較し, 単一粒径のガラス 玉の場合 $C_{0} \Phi_{0}=1, \quad \phi_{\mathrm{s}}=1, \quad \varepsilon=0.383$ (実測值) である ことを考虑して， $C=1220$ であることがわかる， $C_{0} \eta_{0}$ は，単一粒径のガラス玉充てん層に対する混合粒子の通 気抵抗の補正係数であり，コークスの場合その粒度分析 結果から(36) 式により計算できる ${ }^{17)}$.

$$
\begin{aligned}
& \left(C_{0} \Phi_{0}\right) \text { コークス }=0 \cdot 5 \cdot 1 \cdot 06^{k \mathrm{i}} \\
& k \mathrm{i}=I_{\mathrm{s}}^{0} \mathbf{p}^{\circ} \\
& I_{\mathrm{sp}}=100 V \bar{I}_{\mathrm{s}} \bar{I}_{\mathrm{p}} \\
& I_{\mathrm{S}}=D_{\mathrm{I}}{ }^{2} \sum W_{\mathrm{i}}\left(1 / d_{\mathrm{i}}-1 / D_{\mathrm{p}}\right)^{2} \\
& I_{\mathrm{p}}=\left(1 / D_{\mathrm{p}}\right)^{2} \sum W_{\mathrm{i}}\left(d_{\mathrm{i}}-D_{\mathrm{p}}\right)^{2} \cdots \cdots \cdots \cdots \cdots(36-4) \\
& D_{\mathrm{p}}=1 / \sum\left(\mathrm{W}_{\mathrm{i}} / d_{\mathrm{i}}\right)
\end{aligned}
$$

Table 4のデータタら A の試料の值がほぼ中央徝であ

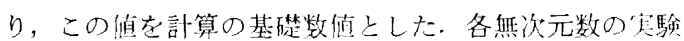
筙四之高炉内推定值は Table 5 の下に示した值を用い た. Table 5 から高炣内の推定值は十分实験筙囲に入つ

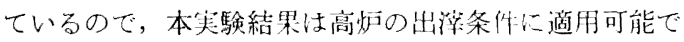
あることがわかる.

モデル実験では流出口は1简所のみで液の液出を行な つた．鼠近の大型高炉は道常２個以上の出銑口を持つ。

2 䈯所以上の出銑口から同時に出㴖する場合には，木お 験結奴は適用できない。しかし，モデル実駼の観察から， 液の流出中に流出口に向けて傾いている液面は, 流出を 停止するとすみやかに水平面になることがわかつてい る.したがつて，2简所以上の出銑口から同時に出洋し ない場合には本実験結果が檤用できる。

\section{2 炉床内の残留溶銑量之残留溶涬量の比較}

上述の実験と解析では，主として溶滓の流出について 检けしたが，この結果を用いて出銑終了時の溶銑と溶洋 
Table 5. Dimensionless numbers at experiments and at the real blast furnace.

\begin{tabular}{|c|c|c|c|}
\hline \multirow{2}{*}{$\begin{array}{l}\text { Dimensionless } \\
\text { number }\end{array}$} & \multicolumn{2}{|c|}{ Range of experiment } & \multirow{2}{*}{ Estimated for the blast furnace* } \\
\hline & Min. & Max. & \\
\hline $\begin{array}{l}F_{\mathrm{r}} \\
R_{\mathrm{eb}} \\
R_{\mathrm{epo}} \\
D_{\mathrm{H}}^{*} \\
R_{\mathrm{v}}^{*}\end{array}$ & $\begin{array}{l}0.05 \times 10^{-9} \\
0.01 \times 10^{-6} \\
0 \cdot 05 \times 10^{-1} \\
0.12 \\
1 \cdot 3\end{array}$ & $\begin{array}{l}500 \times 10^{-9} \\
500 \times 10^{-6} \\
500 \times 10^{-1} \\
1.0 \\
25\end{array}$ & $\begin{array}{c}0 \cdot 25 \times 10^{-9} \\
0 \cdot 051 \times 10^{-6} \\
24 \times 10^{-1} \\
0 \cdot 2-0.35 \\
1 \cdot 5-4 \cdot 0\end{array}$ \\
\hline
\end{tabular}

* Data for calculation

$D_{\mathrm{T}}=1000(\mathrm{~cm}), \quad V_{0}=1 \cdot 710^{-2}(\mathrm{~cm} / \mathrm{sec}), C_{\mathrm{D}}=704(\mathrm{cgs}), \rho=2 \cdot 65\left(\mathrm{~g} / \mathrm{cm}^{3}\right), \quad \mu=4 \cdot 5($ poise $), \quad D_{\mathrm{p}}=2 \cdot 40(\mathrm{~cm})$

の残留量（以下それぞれ残銑量, 残洋量と呼ぶ) の比較 を行なう。

溶銑の容量流出速度は溶滓のそれとほぼ等しい，炉床 の溶銑について Table 5 の各無次元数を計算すると $R_{\mathrm{eb}}$ と $R_{\mathrm{epo}}$ が実験範囲に入らない.しかし，Fig. 8 の結果 が溶銑に対しても適用できると仮定すれば，炉床内の残 銑量と残滓量に関して次のような推定ができる。

溶銑の動粘度は溶滓の動粘度の約 $1 / 150$ であり, 溶銧 の容量流出速度は溶洋のそれとほぼ等しいので，液高さ $D_{\mathrm{H}}$ が同じならば溶銑の $F_{\mathrm{L}}$ は溶滓のそれの約 $1 / 150$ に なる.この場合，溶滓の残留率を $50 \%$ とすると溶銑の 残留率は $5 \%$ 以下となり残銑量は残涬量の $1 / 10$ 以下 (容 量比）となる. また溶銑の $D_{\mathrm{H}}$ を溶滓の々れの $1 / 4$ と 仮定すれば溶鉄の $F_{\mathrm{L}}$ は溶滓のそれの約 $1 / 10$ となり溶 銑の残留率は $20 \%$ 以下（溶滓の残留率 $50 \%$ のとき) でこの場合も残銑量は残滓量の $1 / 10$ となる. 溶銑の残 留寗が小さいことは，溶銑面を水平とした本実験の仮定 の妥当性を裏づけている.

以上の考察から溶滓の液面が出銑口に到達したときに 出銑を終了する場合，出銑終了時の溶沱の残留量は溶銑 の残留量よりいちじるしく多い.したがつて, 炉床の残 留溶融物量の增加による炉況の悪化は溶滓の排出が不十 分なことによる．炉況悪化をさけるためには，溶滓の排 出を十分行なうことが必要である.

\section{3 炉床における溶滓の流れに対するDarcy の式の適 合性の検討}

Darcy の式は砂などの微粒の充てん層中を流れる液体 の単位断面積あたりの流量と圧力損失の関係を示す.こ

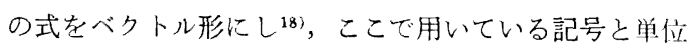
系に合うように変形すると（37）式が得られる.

$$
\begin{aligned}
& \varepsilon \boldsymbol{v}=-\frac{k \rho g}{\mu} \Gamma \Phi \ldots . \\
& \Phi=h+\left(p-p_{0}\right) / \rho g
\end{aligned}
$$

(37) 式は運動方程式に相当し，連繶の式は（39）式に より示される.

$\nabla^{2} \Phi=0$
（33）式を（37）式に代入して書きかえると，

$$
0=-\nabla p-\varepsilon-\frac{\mu}{k} v-\rho g \nabla h \cdots
$$

が得られる. $\mu / k$ は $C_{\mathrm{B}}$ に相当する. (6) 式において 座標軸 z を鉛直方向として考えると（6)，(40) 式の 有辺は一致し，Darcy の式は，（6）式の左辺を無視し たものと見なせる.

$P^{*}$ (41) 式のように定義しなおして，2 章と同様 に (40) 式を無次元化すると（ $\mu / k$ を $C_{\mathrm{B}}$ におきかえて $)$ (42) 式を得る.

$$
\begin{aligned}
& p^{*}=\left(p-p_{0}\right) / \rho g D_{\mathrm{T}} \cdots \\
& \frac{C_{\mathrm{B}} V_{\mathbf{0}}}{\rho g} \boldsymbol{v}^{*}=-\nabla^{*} p^{*}-h^{*}
\end{aligned}
$$

ただし $h^{*}=h / D_{\text {T }}$ である

連続の式と境界条件は 2 章と同樣に無次元化できるの で，师床の溶滓の流れが Darcy の式にしたがう場合に は, 流れは，充てん層の摩擦力と重力の比を示す無次元 数

$$
\frac{C_{\mathrm{B}} V_{\mathrm{o}}}{\rho g}
$$

により決まる，(43) は前述した残留率を決める流出係数 で初期条件の項 $\left(D_{\mathrm{H}}^{*}\right)$ を除いた部分に相当している. こ のことから．炉床の溶㳯の流れは Darcy の式が適用で きる流れであることがわかる.

\section{5. 出銑口からの出㳯の数式シミュレーション}

炉内の蓄積溶㳯量が増して炉況が悪化するのは，蓄積 溶滓量の增加により炉床の液面が上昇し, 炉下部の通気 を妨げるためである，溶滓層の厚さは，出洋開始時にも つとも高くなる．他方高炉操業上出銑作業を一定時間間 隔ごとに行なうことは困難であり, 出銑開始が予定より 遅れる場合を考えれば,残浖量が少ないことが望ましい， したがつて高炉操業上出滓開始時の溶㳯層の厚さ（以下 スラグ高さと呼ぶ）と残滓量が小さくなるように出銑作 業を行なわなければならない。

以上の実験と解析により, 出㳯開始時に炉床にたまつ 
Table 6. Independent variables representing the slag tapping conditions and their estimated value.

\begin{tabular}{l|c|c|c}
\multicolumn{1}{c|}{ Items } & Symbol & Estimated value & Unit \\
\hline Slag tapping rate & $P_{\mathrm{s}}$ & $3 \cdot 25$ & $t / \mathrm{min}$ \\
\hline Slag viscosity & $\mu$ & $4 \cdot 35$ & poise \\
\hline Slag production & $W_{\mathrm{s}}$ & 1800 & $t /$ day \\
\hline $\begin{array}{l}\text { Depth of slag layer at the begining of } \\
\text { slag tapping }\end{array}$ & $D_{\mathrm{HS}}$ & $2 \cdot 755$ & $\mathrm{~m}$ \\
\hline $\begin{array}{l}\text { Hearth diameter } \\
\text { Number of tapping operation }\end{array}$ & $D_{\mathrm{T}}$ & 11.1 & $\mathrm{~m}$ \\
\hline
\end{tabular}

た溶滓量に対する出銑終了時の溶滓残留量の割合 (残留 率）を $F_{L}$ により一義的に示すことができた。しかしス ラグ高さは $F_{L}$ の計算に必要な变数なのでこの結果のみ では，出滓条件（出湍速度，溶滓粘度など）がスラグ高 さ，残滓量などに及ぼす影響を知ることはできない，

本章では，モデル実験結果と炏床での溶㳯量のバラン ス式から, 高炉の出滓に関する独立变数間に関係式（出 滓のシミュレーションモデル）を導き，このモデルを用 いて種々の要因がスラグ高さ，残滓量などに及ぼす影響 を検討する。

\section{1 出滓のシミュレーションモデル}

出滓に関する種々の要因のうち独立変数*としてとり うるものを Table 6 のように選択する. Table 6 に示 す要因以外の要因，たとえば 1 回の出滓時間, 出滓量な どは Table 6 に示した変数を用いて示すことができる.

溶滓の密度は実際の高灯操業ではほとんど変化せず一 定と考えられ, 溶㵏の流出流量. $p_{\mathrm{s}}$ (以下出滓速度と呼 s゙, $t / \min )$ は, 炋床内平均流速 $V_{0}$ と (44) 式の関係 にある。

$$
p_{\mathrm{s}} \propto V_{0} D_{\mathrm{T}^{2}}
$$

実際の高炉炬床のコークス層の空間率, 粒度, 形状係数 を正確に推定することはできないので（32）式中で $\mu$ ， $V_{0}, D_{\mathrm{H}}, D_{\mathrm{T}}$ 以外の項と, (44) 式の比例定数をまとめ てパラメーター

$$
F_{\mathrm{L}}=\gamma \mu p_{\mathrm{s}} / D_{\mathrm{H}^{2}}
$$

により示される.この $F_{\mathrm{L}}$ を用いて溶㳯の残留菜 $\alpha$ は, Fig. 8 の実線を示す関数を $f$ として (46) 式により示 される.

$$
\alpha=f\left(F_{\mathrm{L}}\right)
$$

1 回の出鉄あたりの出湍量は，出滓速度と出洋時間の

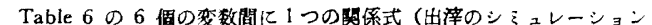
モデル) が成り立つので，般密には，独立変数はてのうちの5 湖(任 意)である.
}

皘（(47）式左辺）および出銑の前後の觇床内溶滓量の減 少（同右辺第 1 項）と出滓時間中の溶滓生成量（同右辺 第 2 項）の和から計算でき（47）式が成り立つ.

$$
T_{\mathrm{s}} p_{\mathrm{s}}=S_{\mathrm{t}}(1-\alpha)+T_{\mathrm{s}} p_{1} \cdots \cdots \cdots \cdots \cdots \cdots \cdots \cdots \cdots \cdots \cdots \cdots \cdots \cdots \cdots(47)
$$

Table 6 の变数を用いると $T_{\mathrm{s}} ， p_{\mathrm{I}}$ はそれぞれ (48)，

(49) 式により示される.

$$
\begin{aligned}
& T_{\mathrm{S}}=W_{\mathrm{s}} /\left(N_{\mathrm{T}} p_{\mathrm{S}}\right) \\
& p_{\mathrm{I}}=W_{\mathrm{s}} / 1440 \cdots
\end{aligned}
$$

一方 $S_{\mathrm{I}}$ は灯床で溶滓がたまる空間の容積から (50) 式 により示される.

$$
S_{\mathrm{I}}=\pi \varepsilon_{\mathrm{c}} \rho D_{\mathrm{HS}} D_{\mathrm{T}}{ }^{2} / 4
$$

$\varepsilon_{\mathrm{c}}=0.35, \rho=2.65$ とし, これらに対する補正と炉床の 有効断面積を設計時の炉床の断面積から求めるときの補 正係数を $\beta$ とおいて (50) 式を（51）式のように変形す る.

$$
S_{\mathrm{I}}=0 \cdot 7285 \beta D_{\mathrm{Hs}} D_{\mathrm{T}}{ }^{2}
$$

（47）式に (48)，(49)，(51) 式を代入して残留率 $\alpha$ を求めると (52) 式が得られる.

$$
\alpha=1-\frac{W_{\mathrm{S}}\left(p_{\mathrm{s}}-W_{\mathrm{s}} / 1440\right)}{0 \cdot 7285 \beta D_{\mathrm{HS}} D_{\mathrm{T}}{ }^{2} N_{\mathrm{T}} p_{\mathrm{S}}}
$$

(46)，(52) 式の右辺を等置して Table 6 に示した要 因間に 1 つ関倸式が得られる.この式(以下出滓のシ ミョレーシェンモデルと呼ぶ) により, Table 6 に示し た要因の任意の 1 変数の変化に対する他の任意の变数の 変化を知ることができる．たとえば，出滓速度が変化し たときのスラグ高さと残㳯量の変化の推定などが可能で ある。

\section{$5 \cdot 2$ 出㳯のシミュレーションモテルの計算方法}

(46), (52) 式の $\alpha$ は, 出滓量 $W_{\mathrm{s}}$ を除く变数に関し て 1 洒の単調增加または, 単調減少関数である. 式を $W_{\mathrm{s}}$ について解くと (53) 式が得られる。

$$
W_{\mathrm{s}}=720 p_{\mathrm{s}} \pm 720 \sqrt{p_{\mathrm{s}}{ }^{2}-\frac{0 \cdot 7285}{360} \beta D_{\mathrm{T}}{ }^{2} N_{\mathrm{T}} p_{\mathrm{S}}(\mathrm{J}-\alpha)}
$$




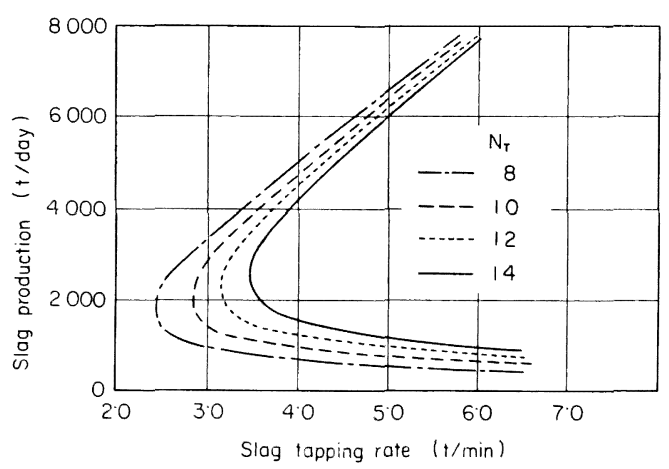

Fig. 9. Relation between slag production and slag tapping rate.

(53) 式から $W_{\mathrm{s}}$ は $720 p_{\mathrm{s}}$ に対称な 2 つの解を持つこ とがわかる、したがつてシミュレーションモデルの解を 求めるとき, $W_{\mathrm{s}}$ については $2 つ$, その他の变数につい てはただ1つの解が得られる。

(46) 式は残留率 $\alpha$ を関数形で与えているのでシミュ レーションモデルを解析的に解くことはできない，そこ で解として求める变数に適当な上限と下限の值 (初期值) を与えて 2 分法による逐次近似により解をもとめた：こ のとき上述の考察から $W_{\mathrm{s}}$ について解くときのみ初期值 の一方（上限值または下限值）に720 p 值を与えて同 一の条件で 2 つ解を求めるようにした.

計算は電子計算機により行ない独立变数の種類と変域 を与えてこ扎江対主る指定した良属变数の变化を求める

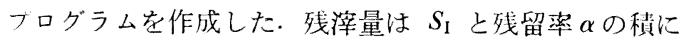
より上述のプログラム中で同時に計算した.

\section{$5 \cdot 3$ 計算結果と考察}

Fig. 9〜Fig. 16 亿計算結果を示す. 困中に示した変 数以外の变数值は千葉 5 高炉 (2 次) の場合に対応させ て求め, Table 6 に示した. パラメーター $\beta$ は 0.9 と し， $\gamma$ は事前の試行錯誤的な松讨により計算結果が 5 高 炉の操業データと対応するように推定值として 0.128 を 用いた。

同一の出㳯速度に対し出沙量は 2 つ值をとり，出滓 連度の増加により増加する場合上減少する場合がある (図 9 ). 前者は流出流量比(出滓速度/スラグ生成速度) が 2 より小さい場合に, 後者は 2 より大きい場合に相当 する*. 出滓速度が 小さい部分で解が存在しないのは (53) 式による解が虚数になることに 相当するが，実際 の操業ができなくなることを示しているのではないた

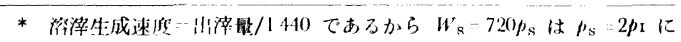
相当している。

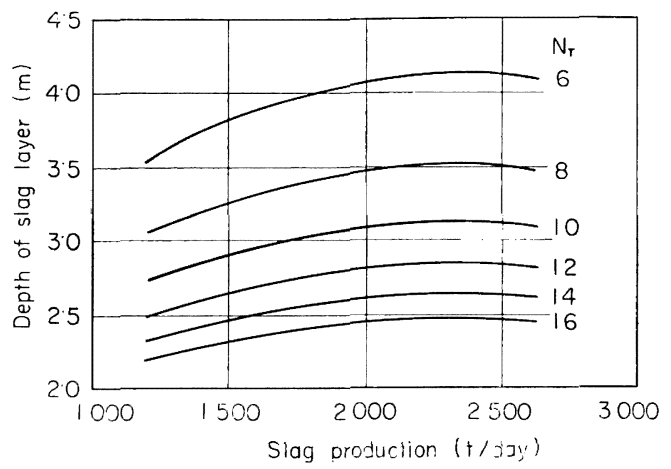

Fig. 10. Relation between depth of slag layer and slag production.

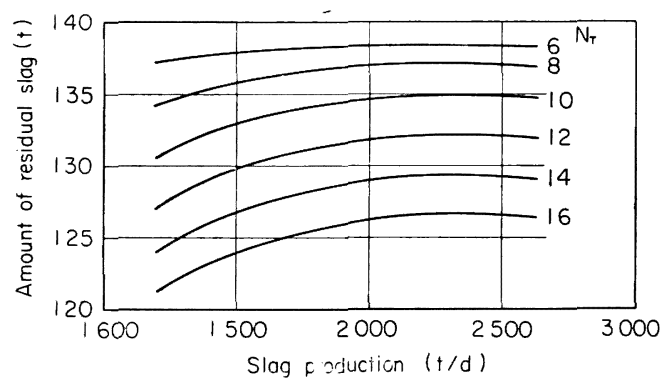

Fig. 11. Relation between the amount of residual slag and slag production.

とえば (53) 式からスラグ高さがここで与えた值 (Table 6 ）より小さくなれば, さらに低い出滓速度で操業が可 能である．また流出流量比が 2 より大きい場合には，出 銑回数の增加により出㳯量は増すが, 逆の場合には出滓 量は減少する (Fig. 9).

出滓量が増したとき, スラグ高さと残滓量は最初増し, つぎに減少する (Fig. 10, Fig. 11)。このとき，スラグ 高さと残滓量は流出流量比が 2 のとき最大になる. 出銑 回数 (Fig. 10, Fig. 11) の減少, 出㳯速度 (Fig. 12, Fig. 13), 溶滓粘度 (Fig. 14, Fig. 15) の増加により, スラグ高さと残䐠量は単調に増加する.

つぎに実際操業中の出滓量, 出銑回数, 出㳯速度, 溶 媇粘度の変動によりスラグ高さ, 残䓋量がどの程度変動 するかを検討する。

出滓量の変動は通常 10\% 程度でありこの程度の変動 によるスラグ高さ，残㴖量の変動は小さく（Fig. 10,

Fig. 11）この影響は無視できる.

出銑回数は変えることができ，スラグ高さを調整する のに有効な手段である. 出銑回数を 12 回から14 回に 増すとスラグ高さを約 7\% 下げることができる (Fig. 


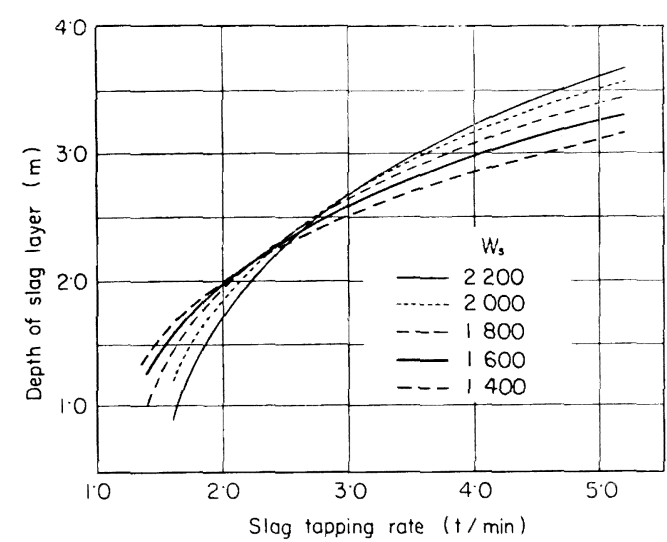

Fig. 12. Relation between depth of slag layer and slag tapping rate.

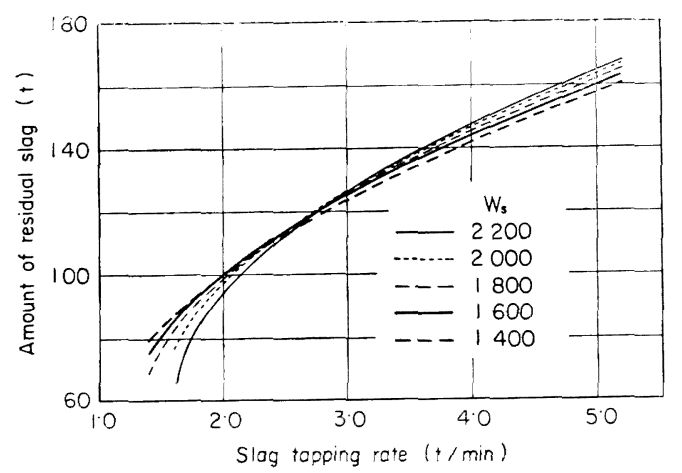

Fig. 13. Relation between the amount of residual slag and slag tapping rate.

10).しかし，この場合残滓量の低下は約 $2 \%$ にすぎな い(Fig. 11).

現状では出滓速度を正確に制御することは困難であ り，場合によつてはその変動幅が $50 \%$ を越えることが ある、出㳯速度がスラグ高さと残洋量に及ぼす影響は大 きく，たとえば出漳速度が $2 t / \mathrm{min}$ から $3 t / \min に$ に增 すと，スラグ高さは約 $35 \%$ (Fig. 12), 残㳯量は約 25 \% (Fig. 13) 増加する.

通常の操業では溶㳯成分の变動は小さいので, 溶㵏粘 度は主として溶滓温度に依存する. 溶㳯温度か $1500^{\circ} \mathrm{C}$ から $1450^{\circ} \mathrm{C}$ に低下すると溶㵏粘度は約 $50 \%$ 增す. 溶 滓粘度が 3.5 ボアズから 4.75 ホアズに增すとスラグ 高さは約 $8 \%$, 残湍量は約 $14 \%$ 増加する (Fig. 14,

Fig. 15).

以上の検砷から，炬床内の蓄積溶滓量の増加による炀 況悪化を防止するためには，第1 に出㳯速度を低く一定 に保つことが重要であり，第２に溶洋温度の大幅な低下

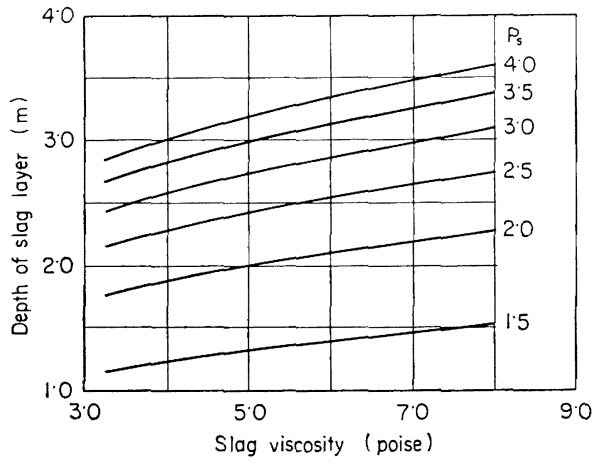

Fig. 14. Relation between depth of slag layer and slag viscosity.

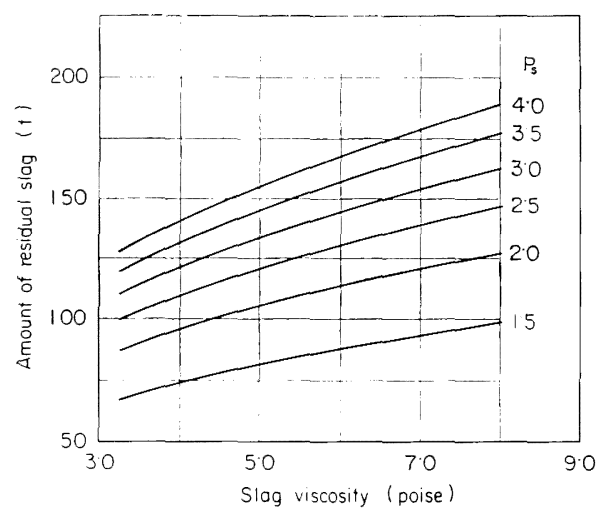

Fig. 15. Relation between the amount of residual slag and slag viscosity.

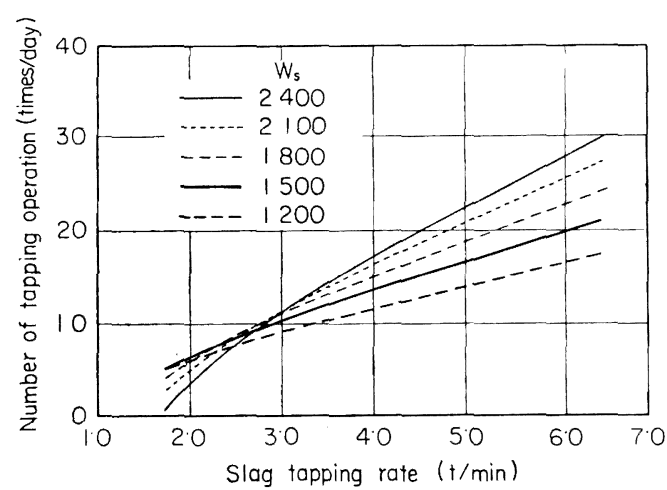

Fig. 16. Relation between number of tapping operation and slag tapping rate.

を避けるように適切な炉熱制御を行なう必要がある.

出㳯速度の増加あるいは，溶㴖粘度の上昇によるスラ グ高さの増加を補僋するための手段として出銑回数を増 すのは有効である.一例として出淮速度が変化したとき 


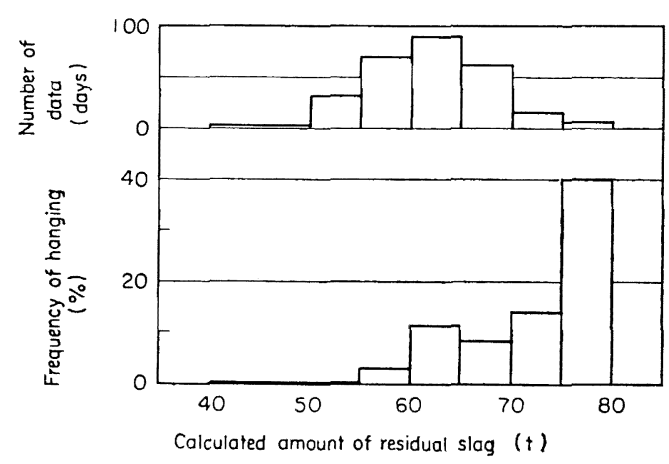

Fig. 17. Relation between frequency of hanging and calculated amount of residual slag and its histgram (based on daily data)

スラグ高さを一定に保つために心要な出銑回数を Fig. 16 に示す. この条件で出銑回数を增した場合，(50) 式

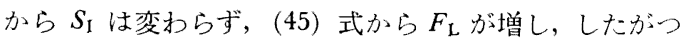
て残留率は增すので，残漳量は增加する。

溶㳯粘度の增加によるスラグ高さの増加を法銑回数の 増加により補償する場合にも残滓量は同忧に増す。出滓 速度が増したときの残滓量の増加率とスラグ高さの増加 率の比は 0.7 であるが，溶滓粘度が増したときのそれは 約 1 .8なので, 出銑回数の増加により出洋速度の増加を 補償する場合より溶㳯粘度の増加を補償する場合の方が 残滓量はより多くなる.

したがつてこのような場合には，とくに出銑遅れのな いように注意して操業する必要がある。

\section{4 出滓のシミュレーションモデによる高炉操業の 解析}

上述した実験は，直接確認できない種々の仮定に基ゔ いて行なつているので, シミュレーションモデルの高炉 操業への適用性を検討するために, シミュレーションモ デルによる残滓量の計算值と棚吊りの関係を調査した.

解析は, 川崎製鉄千菜 5 高炉の昭和 45 年 3 月から 12 月の休風のなかつた日の一日平均の操業データについて 行なつた. Fig. 17 に棚吊りの発生割合と残滓量の関倸 を示す. 棚吊りの発生割合は，計算残滓量により層別し たデータごとにそれぞれのデータ数（日数）に対する棚 吊りのあつた日の割合として求めた，この図から残洋量 が増せば棚吊りが多くなることがわかり，実験の仮定が 妥当であり，シミュレーションモデルが高炉に適用でき ることがわかる.

\section{6. 結言}

高炉の炉況恶化の原因となる炉床の残留溶融物量の増

加の原因を明らかにするために，出滓時に炉床に蓄積し た溶滓がコークス層の間を通つて出銑口に移動するもの として, 溶㳯の流れについて運動方程式と連続の式を導 いた. 式中の变数を無次元化して得たスケールアップの 条件をもとに炉床からの溶滓の流出に関するモデル実験 結果を整理して, 出滓条件と炉床の溶滓残留率の関係を 示したこの関係を利用して出浮の数式シミュレーショ ンを導出し，出㳯開始時の溶渻層の厚さ（大ラグ高さ） と出澾終了時の残留溶滓量（残蒋量）に及ぼす出㳯条件 の影響を明らかにした。吕られた結果は次のとおりであ 万。

（1）炉床内の溶滓の流れは，境界条件，初期条件を 除けば充てん層流れのレイノルズ数 $R_{\mathrm{eb}}$ とフルード数 $F_{\mathrm{r}}$ により決まる。

（2）境界条件，初期条件の影響を含めて，流出開始 時の蓄積液量に対する流出終了時の残留液量の割合（残 留萃) は流出係数 $F_{\mathrm{L}}$ により一義的に Fig. 8 のように 示される.

（3）各無次元数の实験範囲と高炉内の推定值の比較 から Fig. 8 は高炉の出洋に適用できる.

(4) 実験結果の考察から炉床内の溶滓流れに関し て，Darcyの式を適用できる．

（5）溶銑と比較して，溶滓は出銑終了時に炉床内に 残留しやすいので，溶滓の排出を十分行なう必要がある.

（6） スラグ高さと残渼量は, 出滓速度, 溶滓粘度の増 加により増すので，出漳速度を低く一定に保つことと， 溶銑温度の低下による溶渼粘度の上昇をさけるため，適 切な灯熱制御を行なう必要がある.

（7）出滓速度，溶滓粘度の増加時に出銑回数を増す のは, スラグ高さを一定にするための有効な手段である. この場合，残滓量は増すので，とくに出銑遅れのないよ う注意する必要がある.

（8）高炉操業データの解析から出㳯のシミュレーシ ョンモデルにより算出した残漳量が増すと棚吊りが起こ りやすくなることがわかつた。

\section{記 号}

$C:$ レイノルズ数によつて决まる定数 [-]

$C_{0} \Phi_{0}$ ：装入物の種類と粒度分布により決まる 通気抵抗の補正係数 [-]

$C_{\mathrm{B}}$ ：(5)式により定義される充てん層の摩

擦抵抗の係数

$D_{\mathrm{H}}$ ：流出開始時の液体層の厚さ

$D_{\mathrm{Hs}}$ ：出滓開始時の溶涪層の厚さ

$D_{\mathrm{p}}$ : 充てえ档子の調和平均径 $\left[\mathrm{dyn} \cdot \mathrm{sec} / \mathrm{cm}^{2}\right.$ ]

$[\mathrm{cm}, \mathrm{m}]$

[m]

$[\mathrm{cm}]$ 


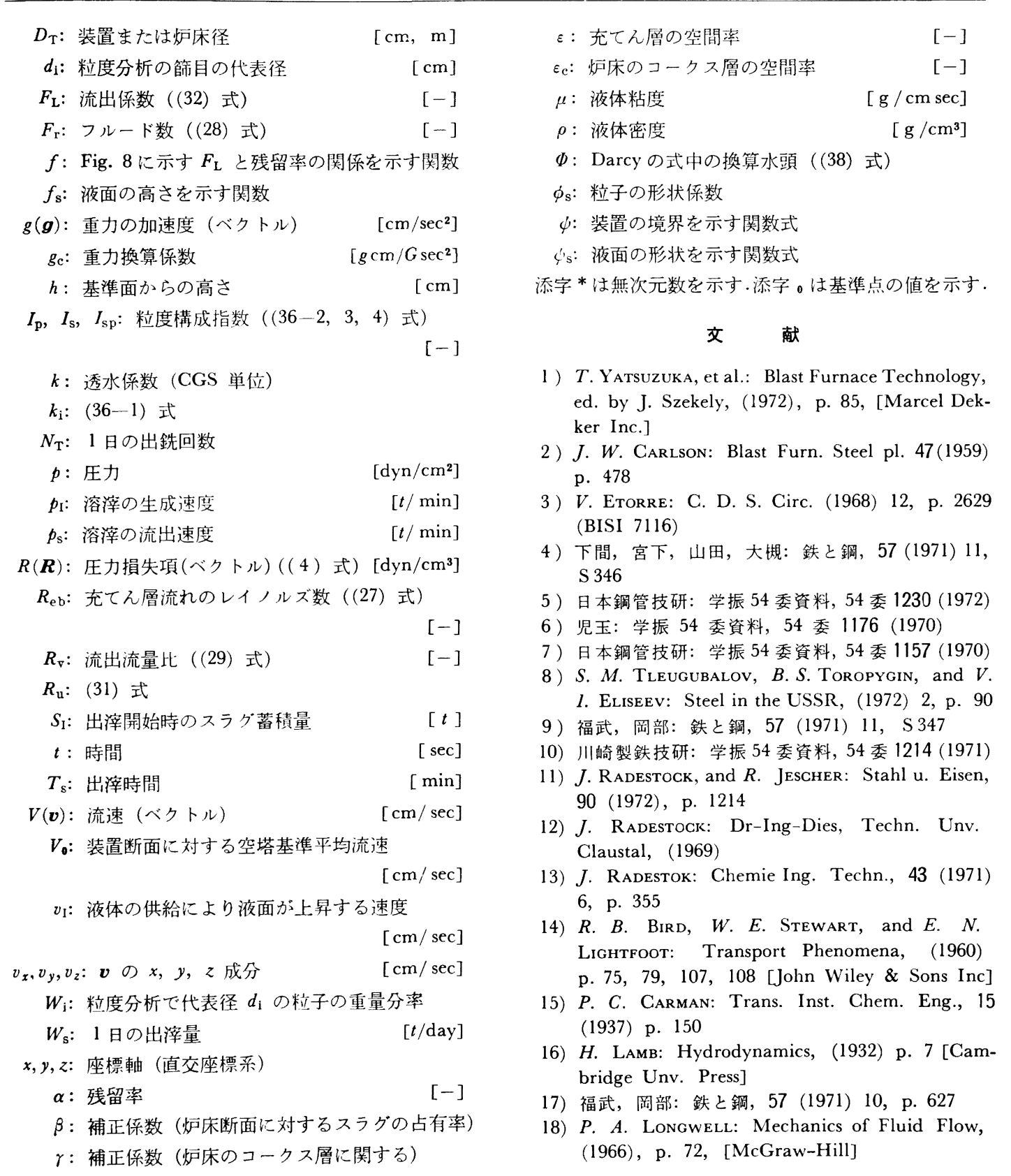

